\title{
ASSOCIAÇÃO PAULISTA DE MEDICINA
}

\section{SECÇÃO DE NEURO-PSIQUIATRIA}

Sessão ordinária - 5, novembro, 1943

PRESIDENTE: DR. ANDRÉ TEIXEIRA LIMA

Sindrome protuberancial. Estudo anátomo-clinico. Dr. Oswaldo Lange

Paciente de 54 anos de idade, com arterio-esclerose e hipertensão artérial, no qual se instalaram distúrbios neurológicos de uma síndrome protuberancial por lesão da parte posterior do terço inferior da hemiprotuberância direita; paralisia facial de tipo periférico e paralisia do motor ocular externo à direita, alem de síndrome sensitiva no hemicorpo esquerdo, excluida a face. Alem destes sinais localizadores, o doente apresentava uma síndrome cerebelar no hemicorpo esquerdo, mioclonias velo-palatinas, mioclonias na mão e ante-braço esquerdos e nistagmo vertical espontaneo. O exame anatomo-patológico, praticado 4 anos após o inicio da moéstia, mostrou lesōes difusas de artério-esclerose prihcipalmente na protuberância com múltiplos focos de amolecimento, entre os quais poude ser identificado aquele que dera inicio à molestia, $O$ caso foi discutido sob $o$ ponto de vista anátomo-patológico, sendo comentada, principalmente, a sintomatologia que, erradamente, fora atribuida à lesões do sistema piramidal, lesões inexistentes nos preparados examinados.

$$
\text { Sessão ordinária - 6, dezembro, } 9143
$$

No expediente foram realizadas as eleiçōes para a nova diretoria, tendo sido eleitos os drs. Paulo Pinto Pupo, Celso Pereira da Silva e José Mario Taques 
Bittencourt, respectivamente para presidente, $1 .^{\circ}$ e $20^{\circ}$ secretários. Foi feita, depois, peio ar. Fernando de Oliveira Bastos, a apresentação e saudação do dr. Ary Borges Fortes, livre-docente de Neurologia na Faculdade de Medicina da Universidade do Rio de Janeiro. $O$ dr. René Ribeiro fez o necrológico do prof. Ulysses Pernambuco, recentemente falecido.

Perturbações sensitivas de origem capsular. Estudo anátomo-clínico. Dr. Ary Borges Fortes.

Este trabalho vem publicado no presente número desta revista.

\section{Sessão ordinária - 5, janeiro, 1944}

PRESIDENTE: DR. PAULO PINTO PUPO

Sobre uma observação anátomo-clínica de siringomielia. Drs. Oswaldo Freitas Julião e Antonio James Brandi.

Este trabalho será publicado na íntegra no próximo número desta revista.

Estudo do líquido céfalo-raquidiano no coma regular $e$ patológico durante a insulinoterapia pelo método de Sakel. Drs. Mario Yahn e João Baptista dos Reis.

Neste trabalho estudamos as modificações encontradas no líquido céfalo-raquidiano no decurso do tratamento insulínico em esquizofrênicos. Em uma primeira série de casos, em número de 9, o líquido cefalo-raquidiano foi tirado durante o coma regular. Em todos os casos algumas alteraçōes foram constantes: a taxa de glicose era sempre baixa e a pressão era alta, sendo que a citologia era normal. A segunda série de casos compreendia um número de 5 doentes em que houve um coma irreversivel, prolongado ou post-hipoglicêmico. Necessitamos de alguns anos para recolher o liquor desses 5 doentes, mas a técnica do exame de laboratório foi sempre a mesma. As alteraçōes encontradas nesta série foram as seguintes: 1) hemorragia microscópica considerada frequentemente como um acidente de punção; 2) pessão alta, mas em grau menor do que nos doentes que tinham um coma regular. Essa hipertensão era explicada como dependendo de uma estase venosa na circulação cerebral ; 3) paralelamente à hiperglicemia, que em tais casos é elevada, o taxa de glicose no liquor era tambem elevada; 4) havia uma modificação qualitativa das células, sem que houvesse um aumento do número de células por $\mathrm{mm}^{3}$. Esse fato representa o achado fundamental das nossas observações. De fato, eram encontrados granulocitos neutrófilos com grande constância, atingindo, em um caso, a taxa de $44 \%$, sendo que as células conservavam sempre o seu aspécto normal. A explicação para isso é dada por uma perturbação na circulação cerebral, de tal maneira que os granulocitos neutrófilos passam atravez das paredes capilares para o espaço perivascular e daí para o líquor.

Tais achados, de acordo com dados clínicos e de laboratório, contribuem para estabelecer uma diferenciação entre o coma insulínico usual e o coma irreversivel, protaído ou post-hipoglicêmico. Juntando este novo sinal caracterisado por uma modificação qualitativa e não quantitativa da citologia do líquor, aos sintomas clínicos, ao comportamento da glicose sanguínea e aos bem conhecidos achados anátomo-patológicos dos comas irreversiveis, fomos levados a sugerir a esse tipo de acidente do tratamento de Sakel a denominação de "coma insulínico patológico". As amostras de liquor foram colhidas em todos os casos pela punção cisternal. 